\title{
Evidens og kreativitet
}

\author{
Af Christine Nordentoft
}

\begin{abstract}
Formålet med artiklen er at undersøge, hvordan nye ideer og tiltag opstår i folkebibliotekerne. Hvilken rolle spiller begreber som kreativitet og innovation? Findes der anbefalinger til procedurer, der fremmer kreativitet og innovation? Benytter folkebibliotekerne sig af forskningsresultater og $i$ hvilken udstrcekning ligger der forskningsresultater til grund for folkebibliotekernes ideudvikling? Hvordan forholder professionen sig til ideen om evidensbasering? Hvilke muligheder, fordele og ulemper måtte der vare for professionen? Som teoretisk baggrund for undersøgelsen benyttes Tanggaards kreativitetsteori, Styrelsen for Bibliotek og Mediers rapport om det innovative bibliotek og Rieper og Foss Hansens analyser af evidensbevagelsens metodedebat. Der er $i 2010$ foretaget seks kvalitative interviews med ledere i folkebiblioteker fra Danmarks fem regioner. Det undersøges, hvorvidt nye ideer og tiltag opstår tilfceldigt, eller om de er baseret på forskningsresultater. Der konkluderes ud fra undersøgelsen omkring folkebibliotekslederes holdning til sammenhoeng mellem kreativitet og innovation på den ene side og evidensbaseret praksis (EBP) på den anden. Hverken Tanggaards teori eller opfattelsen hos flertallet af interviewede biblioteksledere giver tilsyneladende belog for at hoevde, at der skulle vore en - reel eller oplevet - modscetning mellem evidens-baseret praksis $(E B P)$ og kreativitet og innovation.
\end{abstract}

Christine Nordentoft er studielektor, cand.scient. bibl. ved Det Informationsvidenskabelige Akademi. cn@iva.dk

\section{Indledning}

De senere års samfundsmæssige og teknologiske ændringer har haft dybtgående konsekvenser for folkebibliotekernes virksomhed. De er i dag underlagt et udviklingspres, der konstant kræver både kreativitet $\mathrm{i}$ form af nye ideer og innovationer og stadig ny læring. Bibliotekerne skal leve op til et samfund under stadig forandring med nye behov, en ændret medieudvikling og borgernes ændrede og meget forskellige behov. Folkebibliotekerne er derfor nødt til at være i front og forholde sig proaktivt til dette pres såvel internt som eksternt i samarbejde med nye partnere. Det kræver tilsammen en stærkere kontrol og garanti for kvaliteten af innovative tiltag. Hvordan forholder folkebiblioteket sig til denne udvikling og hvilke metoder tages i anvendelse med henblik på at imødekomme kravene? Hvor kommer ideerne og innovationerne fra? Mener folkebibliotekernes ledere, at kreativiteten kan få frit spillerum samtidig med, at evidensorienterede metoder til måling af effektivitet og kvalitet tages i anvendelse?

Denne artikel vil undersøge, hvordan folkebibliotekerne takler udviklingspresset. Hvordan udvikler ideer sig inden for professionen? Hvad er holdningen til kreativitet og innovation? Hvilken rolle spiller begreber som kreativitet og innovation? Er det en udbredt holdning, at kreativiteten hæmmes, når vi taler evidensbasering?

Begrebet kreativitet tager i denne artikel udgangspunkt i Tanggaards teori om, at kreativitet er noget, 
der skal læres (2008) og i Styrelsen for Bibliotek og Mediers rapport om det innovative bibliotek (2006). Artiklens anvendelse af evidensbegrebet bygger på Rieper og Foss Hansen. (2007) og delvis på Booth \& Brice (2004). Undersøgelsen fokuserer på en række udvalgte biblioteker og institutioner.

Artiklen vil forsøge at besvare følgende forskningsspørgsmål:

- Hvilken rolle spiller begreber som kreativitet og innovation for nye interventioner?

- I hvilke fora opstår kreativitet og innovation i folkebiblioteker?

- Kan kreativitet læres?

- Findes der anbefalinger til procedurer for ideudvikling?

- Hvad er grundlaget for at vælge en ide til eller fra?

- Er der spor af erfaringsbaseret evidens i folkebibliotekerne?

- I hvilken udstrækning benytter folkebibliotekerne sig af forskningsresultater?

- I hvilken udstrækning ligger forskningsresultater til grund for folkebibliotekernes ideudvikling?

- Hvad er folkebibliotekernes holdning til evidensbasering af innovationer?

\section{Kreativitet}

Kreativitet er et bredt begreb, og der er delte meninger om, hvor omfattende definitionen på kreativitet skal være. Ifølge Kollerup (2005, s. 45-47) er kreativitet noget nyt og nyttigt. Innovation er kreativitet, der lykkes, i den forstand, at resultatet kan patenteres og/eller er salgbart. Ifølge Pratt og Jeffcut (2009) er innovation helt afhængig af kreativitet i udviklingen af nye produkter og services. Kreativitet og innovation er i den opfattelse tæt forbundne begreber: "uden kreativitet har vi ingen innovation, og uden innovation mindsker vi overskuddet til kreativiteten." (Kollerup, 2005). I følge Darsø (2001) kan starten på en innovation beskrives således:

"At best it is described as a chaotic or turbulent phase with certain individuals as central actors who make use of informal networks, intra-and inter-organizationally.”(Darsø, 2001, s. 31-32) .

Innovation indledes altså med en kaotisk og turbulent fase. Denne fase minder om den traditionelle opfat- telse af kreativitet (Tanggaard, 2008). Hos Tanggaard defineres kreativitet ydermere, som noget man skal lære i praksis (Tanggaard, 2008), en definition, der åbner for at forbinde kreativitet og innovation med evidensbasering af fx ideudvikling.

Folkebibliotekerne skal få ideer, turde prøve nyt og udvikle nye og bedre produkter. Men hvad gør mennesker for at blive kreative? Hvor kommer kreativiteten og nytænkningen fra? Er det noget medfødt? Eller kan man skabe arbejdspladser, hvor kreativitet og innovation får mulighed for at blomstre?

Kreativitet er som sagt et diffust og mangetydigt begreb. Det er faktisk nemmere at sige, hvad kreativitet ikke er, end hvad det er. Ordet kreativitet betyder, som tidligere nævnt at skabe - underforstået noget nyt - og kreativitet anses traditionelt for at være idéer, der opstår spontant og ubevidst som et tankemæssigt spring. Man opererede tidligere inden for kunsten med Musen, der steg ned og inspirerede digteren; senere opstod tanken om kreativiteten som en medfødt evne og gave til det enkelte individ $\mathrm{fx}$ en Goethe eller en Einstein. I den opfattelse var det produktet af kreativiteten, der var interessant; den kreative proces interesserede man sig ikke for eller forstod, at der overhovedet kunne være en proces. Muligheden af at lære at være kreativ kom derfor ikke på tale. I dag er der flere bud på forståelse af kreativitet og den kreative proces, der peger på, at vi alle kan være kreative - i større eller mindre grad - og at kreativitet kan læres. Ifølge Tanggaard (2008, s.

50) kan man:

"lære at være kreativ, hvis det fastholdes, at kreativitet ikke er et resultat af guddommelig inspiration eller pludselige indfald, men tværtimod er et fænomen, som kan beskrives og forstås som et led i udvikling og forandring af menneskelige praksisser"

Praksisser eller praksisfællesskaber er her defineret som et sæt af relationer mellem personer, aktiviteter og deres omverden over tid og i relation til andre overlappende praksisfællesskaber, hvor man arbejder på et fælles projekt (Tanggaard, 2008). Samtidig forudsætter kreativitet, at man har opnået viden og færdigheder inden for sit arbejdsområde ved igennem længere tid at have arbejdet inden for et praksisfælleskab, domæne eller arbejdsområde. Har man deltaget længe nok i en bestemt praksis, vil man have opnået 
den basisviden, der forudsættes for at være kreativ og innovativ:

"Læring bliver vigtig for kreativitet i den forstand, at kreativitet forudsætter viden og færdigheder inden for eksisterende praksis - man skal have lært at kende disse praksis for at kunne transformere dem." (Tanggaard, 2008, s. 50)

Det skal bemærkes her, at der inden for evidensbevægelsen også fokuseres netop på kombinationen af teori og praksis.(Booth \& Brice, 2004). Samtidig anfører Tanggaard, at

"Ens verden skal være stor nok, for at man kan blive ved med at være kreativ...", det er ..."ikke nok bare at være kreativ med de ting, man allerede kender. Man skal kende til omkringliggende viden og den nyeste udvikling på sit felt for at kunne drage det ind i sin egen praksis" (Tanggaard, 2008, s. 79)

Her er altså en indirekte men klar opfordring til at inddrage den bedste og den nyeste forskningslitteratur på sit felt. At følge med i den nyeste forskning kræver imidlertid fordybelse og tid, faktorer der ikke er for meget af i den daglige, stressede praksis. Netop tid spiller - ifølge Tanggaard (2008) - en væsentlig rolle for kreativitet. Hun peger på, at fordybelse i materialet over længere tid fremmer kreativitet og dermed innovation. Men det er ofte et problem - også inden for folkebibliotekssektoren - at finde tiden til fordybelse. Inden for universitetsverdenen kan publiceringsaktivitet og fondsansøgninger være en trussel mod denne fordybelse, og inden for undervisning, hvor eleverne konstant skifter emne, blokeres mulighederne for fordybelse ligeledes. I biblioteksverdenen opstår problemet i forbindelse med kravet om fornyelse på alle fronter fra omverden og arbejdsplads.

Udover at skabe rum og tid nævner Tanggaard(2008) andre produktive, kreativitetsfremmende metoder såsom grænsekrydsninger mellem forskellige praksisfællesskaber, idet det skaber ny læring, når erfaringer fra et felt overføres til et andet i forbindelse med at forskellige praksisfællesskaber begynder at koordinere deres interesser og begynder at stille uvante spørgsmål. Hvis Tanggaards teori om, at innovation og nyskabelser vokser nedefra omkring praksisfælleskaber antages, vil evidensbasering af bibliotekspraksis kombineret med en systematisering af læring i praksisfællesskaber kunne bidrage til en større grad af kreativitet og nyskabelse. Denne opfattelse afspejles i Booth \& Brices (2004) tanker om blød evidens. Tanggaard (2008) nævner også vigtigheden af, at den omkringliggende viden, den nyeste udvikling inden for et område, er nødvendig og danner belæg for at inddrage den hårde evidens $\mathrm{i}$ form af primærstudier med videnskabelige kontrollerede spørgsmål og logiske ræsonnementer formidlet gennem systematiske reviews. Tanggaard er her helt i tråd med Rieper og Foss Hansen (2007), der er eksponenter for hård evidens. Kvaliteten af nye innovationer sikres derfor tilsyneladende bedst med evidensbaseret viden fra praksisområdet (blød evidens) kombineret med tid til og fordybelse $\mathrm{i}$ forskningsresultater altså hård evidens. Hvis kombinationen af praksis og teori er den bedste forudsætning for kreativitet, kommer EBP ind som medspiller til kvalitet i kreativitet og dermed innovation.

\section{Innovation}

Flere læringsteoretikere beskriver ligesom Tanggaard læring og praksisfællesskaber som udgangspunktet for kreativitet og innovation. At innovation typisk vokser op nede fra i en organisation, betyder at den skal organiseres og ledes i overensstemmelse hermed. Nogen får en ide og begynder at arbejde sammen på den, og ledelsen skal sikre, at alle i organisationen arbejder mod det eller de samme mål. Det kræver en innovationsstrategi, der understøtter læring og praksisfællesskaber.

"For at kultivere innovation og kreativitet på arbejdspladsen mener Brown \& Duguid (1991), at organisationer skal tage hensyn til de praksisfællesskaber, der naturligt opstår som svar på organisationens mange opgaver. En innovativ organisation er, siger de, organiseret som en kreativ samling af praksisfællesskaber.” (Tanggaard, 2008, s. 87)

Hvis organisationen skal være innovativ, skal man sikre sig, at den har en innovationsstrategi. Man skal være bevidst om, hvilke elementer, der indgår i strategien, hvordan de er integreret, hvilke innovationsnetværk, der eksisterer internt som eksternt, hvorvidt kreativitet stimuleres og evt. belønnes. Man skal vide, hvordan organisationen beskrives, hvorvidt den støtter ideer uden for den nuværende strategi og hvilke barrierer, der er for innovation. Vigtigt er også i hvor stort omfang, de ansattes ideer og kreativitet 
impliceres i organisationens innovationer, og i hvilke henseender organisationen er innovativ:

"Davila, Epstein og Shelton anbefaler at man udvikler en decideret innovations-portefølje i virksomhederne. Her må det overvejes, hvilken kombination af gradvise, semi-radikale og radikale innovationer, man har tænkt sig at satse på”. (Tanggaard, 2008, s. 95)

\section{Innovation i folkebiblioteker}

Som nævnt oven for, er det nødvendigt, at bibliotekerne hele tiden fornyr sig, hvis de skal gøre sig gældende $\mathrm{i}$ fremtidens samfund. Styrelsen for Bibliotek og Medier har bl.a. til opgave at fokusere på markedsføring af bibliotekerne og bibliotekernes tilbud og at samarbejde med organisationer og institutioner, som kan bidrage aktivt i forhold til biblioteksudviklingen. Ifølge Styrelsen for Bibliotek og Medier er:

"det globale innovationssamfund kendetegnet ved, at de fleste danske virksomheder og mange offentlige organisationer står over for nye og skærpede vilkår som:

-Stadig mere krævende kunder og brugere -Hurtig teknologisk forandring og udvikling -Skarp konkurrence med konkurrenter og udbydere, som kan fremvise dramatiske fordele på omkost ningssiden.”(Mandag Morgen, 2006, s. 6)

Debatoplægget "Virker velfærden" (Mandag Morgen, 2005) argumenterer for, at store dele af den offentlige service er baseret på tro og forhåbninger - og at der er brug for en langt mere kritisk afprøvning af, om indsatsen virker. Det er dokumenteret, at nogle velmenende offentlige indsatser i realiteten ingen effekt har eller slår fejl. Et nøgleredskab kunne derfor være flere kontrollerede forsøg og eksperimenter, ligesom en mere videnbaseret offentlig service handler om muligheden for faglig udvikling blandt de offentlige ansatte. Det samme billede kan siges at gælde for folkebibliotekerne ikke alene i et nationalt perspektiv, men også i et internationalt perspektiv. Hvis bibliotekerne skal beholde en central rolle $\mathrm{i}$ samfundsudviklingen i stedet for at blive udkonkurreret og overflødige, er det nødvendigt, at bibliotekerne deltager som strategiske partnere i det omgivende og i det globale samfund, ligesom fol- kebibliotekerne også må forny sig i forhold til både brugernes krav og til egen faglig opkvalificering.

"De danske folkebiblioteker er dygtige til at udvikle nye og attraktive ydelser for brugerne. Adskillige undersøgelser viser dog paradoksalt nok, at mange borgere og brugere aldrig har hørt om disse nye ydelser. Her mener Bibliotek og Medier, at bedre markedsføring og kompetenceudvikling kan være nogle af nøgleordene. "(Styrelsen for Bibliotek og Medier, 2010).

Ifølge dette citat mangler folkebibliotekerne ikke kun bedre markedsføring men også kompetenceudvikling. Man kan spørge sig selv, hvorfor så godt et koncept som biblioteket har så svært ved at markedsføre sig selv? Umiddelbart kan det se ud, som om det er markedsføringen og formidlingen, som det står ringe til med; men Mandag Morgen, (2006) gør opmærksom på, at selvom bibliotekerne har ført mange og gode kampagner med udvikling af plakater, flyers m.v., er det alligevel kun et fåtal, der kender til innovationer som $\mathrm{fx}$ musikdownloads via netmusik. dk., der kan udføres gratis hjemmefra via bibliotekets hjemmeside. I en overordnet biblioteksstrategi og vision er det imidlertid ikke blot nødvendigt at udvikle nye ideer, men også at samme ideer er baseret på dokumentation for ideernes kvalitet. Det skal sikres at:

"bibliotekerne som public service institutioner bidrager med deres kompetencer til samfundsudviklingen, højere kvalitet, øget brugertilfredshed, intern effektivisering og fornyelser" (Mandag Morgen, 2006, s. 6)

Bibliotekerne skal ikke alene udvikle og formidle unikke produkter og aktiviteter, både virtuelt og fysisk, men også sikre, at det er de rette produkter af høj kvalitet. Det er vigtigt, at bibliotekerne skaber efterspørgsel på produkter, som kun bibliotekerne kan levere, eller som kun bibliotekerne kan levere med den nødvendige kvalitet. Det er derfor vigtigt for bibliotekerne at skabe et kvalitetsbaseret grundlag for udviklingen af nye tiltag og aktiviteter:

"Gode innovationer kræver en optimal innovationsstrategi, at alle medarbejdere ikke kun ledelsen inddrages og at organisationer ikke kun samarbejder med interne partnere, men også med eksterne innovationskilder, som forskere, eksperter, samarbejdspartnere, skoler og kunder - og gør det glo- 
balt. Man kalder det "open innovation". "(Mandag Morgen, 2006, s. 6)

Ifølge Mandag Morgen(2006) har de danske medarbejdere mere ansvar og selvstændighed, end nogen andre medarbejdere i verden. Den danske arbejdsorganisation er derfor central med henblik på at skabe innovation:

"Den danske innovationsmodel repræsenterer en samarbejdsmodel, der i højere grad end andre forløser kreativitet...”(Mandag Morgen, s. 11) Samtidig har: Danmark ifølge ny forskning verdens mest innovative forbrugere.” (Mandag Morgen, s. 13)

Der er altså et stort behov for kompetenceudvikling i forhold til innovation. Der er både behov for en opkvalificering af nuværende medarbejdere og en innovationsstrategi, der peger fremad. En mere strategisk tilgang til innovation herunder udarbejdelse af innovationsregnskaber er et vigtigt redskab også for offentlige organisationer:

"Under alle omstændigheder vil bibliotekerne kunne ruste sig til fremtidens udfordringer ved allerede nu at stille spørgsmålet, hvordan innovationskapaciteten i biblioteksvæsenet bedst kan dokumenteres og måles over tid." (Mandag Morgen, s. 20)

\section{Evidensbegrebet}

Evidensbevægelsen er af ældre dato og har rødder i det medicinske område. I 1930érne og 40érne eksperimenterede man med kontrollerede lodtrækningsforsøg, og i 1970érne skrev epidemiologen Archie Cochrane på baggrund af begrænsede ressourcer inden for sundhedsvæsenet, at det var helt nødvendigt at prioritere ressourcerne ud fra tests. Medicinsk viden og prioritering skulle være evidensbaseret. Senere har bevægelsen forplantet sig til mange andre områder:

"Evidensbasering handler om at udarbejde politik, forvaltning, praksis etc. med afsæt i den bedst mulige viden om, hvilke indsatser der virker henholdsvis ikke virker" (Rieper \& Foss Hansen, 2007, s. 13)

Med henblik på at opnå den bedst mulige viden forsøger man at identificere alle relevante primærstudier, der tager sigte på en given problemstilling. Denne viden formidles så i form af systematiske reviews. Til brug for udvælgelse af den bedste viden arbejder man i mange evidensproducerende organisationer med et evidenshierarki.

Hierarkiet er stærkt influeret af de naturvidenskabelige forskningsidealer og placerer lodtrækningsforsøg/ Random Controlled Trials (RCT) øverst, mens kvalitative undersøgelsesdesigns først optræder nederst i hierarkiet (Rieper \& Foss Hansen, 2007). Evidenshierarkiet kontrasterer derfor med beslutningstagen i praksis, der mere bygger på intuition, instinkt eller praksisbaseret viden uden dokumentation end på eksplicitte og logiske videnskabelige resultater endsige et samarbejde mellem forskning og praksis. Dette forhold kan ikke siges at udfordre gængse praksisser og metoder. Ydermere synes det, at mange professionelle glemmer den oprindelige baggrund og det oprindelige formål med anvendt praksis og som nævnt tidligere, kommer dertil, at der sjældent er tid til fordybelse eller fornyelse af indlært viden med henblik på at skabe ny kreativitet og innovation. I stedet er konsekvensen ofte at:

" decisions are based on little more than instinct or colleagues'opinion, and that as a result their decision making may be ill-informed and high-risk. It is further claimed that this situation indicates a 'communication gap' between researchers and practitioners..." (Booth, 2004, s. 49)

Udarbejdelsen af de systematiske reviews består i at inkludere de bedste primærstudier og ekskludere andre ud fra en opfattelse af, at ikke alle vidensformer er lige gode. Dette arbejde udføres af særlige evidensproducerende organisationer inden for evidensbevægelsen på flere forskellige videnskabsområder $\mathrm{fx}$ medicin (Cochrane samarbejdet). I forbindelse med evidenshierarkiet er der fortsat løbende diskussion inden for evidensbevægelsen omkring "hård" eller "blød" evidens, dvs. hvorvidt den identificerede viden skal være baseret udelukkende på "hård" evidens som RCT, eller om man også kan forsvare blød evidens i form af kvalitative studier som legitim. Tilhængere af den "hårde" evidens vægter RCT højest i forhold til effektivitetsspørgsmål, altså om en indsats virker eller ikke. Fortalere for en mere "blød" kontekst- og situationsafhængig evidens lægger vægt på, at kvalitative designs og erfaringsbaserede undersøgelser har deres berettigelse i forhold til andre problemstillinger, hvor det handler om, hvorfor eller 
hvorfor ikke en bestemt indsats virker eller det modsatte:

"Tilvejebringelsen af erfaringsbaseret viden kan organiseres enten som en monitorering af en konkret organisatorisk praksis eller som en netværksaktivitet, hvor flere beslægtede organisationer indsamler erfaringer og sammenligner på tværs." (Rieper \& Foss Hansen, 2007, s. 35)

Som tidligere nævnt har Styrelsen for Bibliotek og Medier påpeget, at der er behov for faglig udvikling og for en opkvalificering af bibliotekssektorens medarbejdere, et udgangspunkt, der advokerer for inddragelse af både hård og en blød evidens. Griber vi tilbage til afsnittet om kreativitet, så vi, at læring ifølge Tanggaard (2008) er vigtig for kreativitet, fordi kreativitet forudsætter viden og færdigheder om eksisterende praksis. Samtidig skal ens verden være stor nok for, at man kan blive ved med at være kreativ; det er ikke nok bare at være kreativ med de ting, man allerede kender. Man skal kende til omkringliggende viden og den nyeste udvikling på sit felt [min fremhævelse, CN] for at kunne være kreativ og dermed innovativ. Dette peger på, at både blød og hård evidens med inddragelse af forskningsresultater er vigtig for innovation. Da kreativitet og innovation (Mandag Morgen, 2006) tilsyneladende udvikles i praksisfællesskaber, vil en fælles strategi, der inddrager såvel praksis som evidensbaseret forskning, være frugtbar også inden for folkebibliotekssektoren med henblik på udvikling af nye innovationer. Det er på den baggrund interessant at se nærmere på, hvorvidt danske folkebiblioteksledere udviser spor af evidens i praksis, hvorvidt de benytter sig af forskningsresultater og i hvilken udstrækning, der ligger forskningsresultater til grund for folkebibliotekernes innovationer.

\section{Metode}

Undersøgelsen består af kvalitative interviews med biblioteksledere og udviklingschefer. Der er gennemført interviews med seks folkebiblioteksledere. De deltagende biblioteker repræsenterer hver sin region i Danmark undtagen Bornholm. Hvert interview har et omfang på maksimalt en time, og alle er anonymiserede. Af dokumentationshensyn er interviewene optaget på bånd. Interviewene er gennemført som forholdsvis åbne interviews, der er strukturerede i forhold til de neden for nævnte temaer. Til hvert tema er der udarbejdet en række mere specifikke spørgsmål.

Følgende interviewtemaer berøres:

Kreativitet: Hvordan defineres kreativitet i folkebibliotekerne? Kreativitet i forhold til emner som holdninger og værdier, understøttelse af kreativitet. Fora for kreativitet, arbejdsprocesser og beslutningsstrukturer omkring kreativitet, ansattes og lederes opfattelse af og deltagelse i kreative processer. Eventuelle belønningsmønstre. Kreativitet inden for videns- og kompetenceudvikling.

Innovation: Hvordan defineres innovation? Innovation i biblioteker i forhold til emner som arbejdsprocesser, beslutningsstrukturer og fora. Ansatte og lederes opfattelse og deltagelse i innovative processer. Eventuelle belønningsmønstre. Innovation inden for videns- og kompetenceudvikling.

Evidensbasering: Hvordan defineres evidensbasering? Evidensbasering af innovationer i biblioteker i forhold til emner som fortrolighed med evidensbaseret biblioteksfunktion. Benyttelse af forskningsresultater i biblioteker, ledelse og ansatte. Holdninger til evidensbasering.

\section{Resultater}

Folkebibliotekernes holdninger til begreberne kreativitet og innovation

Undersøgelsen viser, at begrebet kreativitet stort set opfattes ens af alle interviewede ligesom ledernes forestilling om, at medarbejdernes opfattelse af begrebet kreativitet stemmer overens med ledernes opfattelse af begrebet. Ord som spontanitet, tænke ud af boksen, tænke utraditionelt, skabe noget nyt, noget anderledes, gode ideer, ikke gøre som vi plejer, kombinere kendte elementer på en ny måde, iderigdom, leg og glæde dukker op i flere interviews og tegner et billede af begrebet kreativitet, hvor der er en god overensstemmelse mellem de interviewedes opfattelse af kreativitet og den traditionelle opfattelse af kreativitet som idéer, der opstår spontant og ubevidst som et tankemæssigt spring. Ordet kreativitet betyder, som tidligere nævnt, at skabe - underforstået noget nyt. I den opfattelse er det produktet af kreativiteten, der er fokus på. Selve den kreative proces forstås dog gennemgående af alle interviewede som en proces, der opstår i et fællesskab. Det er opfattelsen, 
at de fleste mennesker kan være kreative, men at de bliver endnu mere kreative i samspil med kolleger, forskellige faglige miljøer og faggrupper. Der er bred enighed om, at det enkelte menneske kan være mere eller mindre kreativt, men at kreativitet tydeligst kommer frem i et samspil med andre, at det er vigtigt at sætte folk sammen og helst forskellige faggrupper for derigennem at skabe et kreativt miljø:

"jeg opfatter egentlig også kreativitet meget, som noget der udspiller sig eller opstår i en relation mellem forskellige mennesker og netop forskellige mennesker, at det er noget der kan opstå i en positiv dialog."

"Jeg ville have svært ved at sidde sådan på kommando og være kreativ, men det kan godt ske, jeg kan være kreativ sammen med dig, hvis vi lod bolden gå frem og tilbage nogen gange.”

De interviewedes traditionelle opfattelse af kreativitet som et individuelt tankespring eller en inspiration, ser derfor ikke ud til at have nogen nævneværdig indflydelse på opfattelsen af udvikling af kreativitet som en fælles praksisproces. Undersøgelsen viser mange eksempler på, at det er praksisfællesskabet, der skaber kreativitet, og at det er en fordel, at forskellige faggrupper og folk med forskellige uddannelser sættes sammen i teams og projekter. Der er derfor god overensstemmelse mellem de adspurgte biblioteksledere og udviklingschefer og Tanggaard (2008) i synet på kreativitet, som noget der opstår i praksisfællesskaber over tid. I rapporten fra Styrelsen for Bibliotek og Medier (2006), nævnes, at folkebiblioteket er gået fra en monokultur til en kultur med medarbejdere med forskellig uddannelsesmæssig baggrund, et forhold, der også kan ses som en styrkelse af kreativiteten. Den udbredte men traditionelle opfattelse af kreativitet som noget der opstår spontant, er altså ikke noget der hæmmer tanken om den fælles praksis som drivhus for kreativitet i folkebibliotekerne. Enkelte af de interviewede taler dog også om en mere individualistisk opstået kreativitet:

"det er tit, når jeg står i badet at så er den der, Gud det kunne man gøre."

Her kobles der dog straks efter videre til vigtigheden af netværk og engagement og interesse for sagen som noget helt grundlæggende for kreativitet. De tilsyneladende individuelt opståede ideer vil derfor af de adspurgte typisk ses som vokset ud af lang tids læring i et praksisfællesskab på organisationsniveau og på eksternt niveau gennem netværk. Det vil sige, at det overordnet først og fremmest er den fælles arbejdspraksis - det være sig på ansat eller på lederniveau - der med interne og eksterne kolleger, netværk, nationale som internationale, og læring over tid, befordrer kreativiteten frem for spontant opståede ideer, selvom de forekommer.

\section{Hvad forstår du ved begrebet innovation?}

Begrebet innovation defineres som en positiv nyudvikling, der er mere målrettet end kreativitet. Kreativitet er en forudsætning for innovation, og innovation er at få udført nogle af de ting, man kunne forestille sig at gøre, lave nye tilbud eller nye arbejdsgange. Innovation er iværksættelsen af den kreative ide. Kreativiteten er forudsætningen for bibliotekernes innovationer og det innovative er det at få det gjort. Innovation defineres af nogle som et hjul, der løber i modsætning til kreativitet, der godt kan være øjeblikkelig og spontan jævnfør den traditionelle kreativitetsopfattelse. Innovation defineres som værende mere end kreativitet, det er mere styret og indeholder flere elementer, noget nyt og noget, der skal have nytteværdi. Dette harmonerer med Tanggaards(2008) og Mandag Morgens (2006) opfattelse af begrebet innovation. Alle interviewede formoder, at medarbejderne hovedsagelig har samme opfattelse af begrebet innovation, som de selv har nemlig iværksættelsen af den kreative ide.

\section{Kan man lære at være kreativ?}

Kreativitet kan ifølge undersøgelsens respondenter til en vis grad læres; enkelte steder har medarbejdere været på kreativitets workshops eller på en uddannelse inden for kreativitet. Det er flere steder opfattelsen, at rigtig mange mennesker, der ikke troede, de var kreative, har et potentiale for kreativitet. En enkelt biblioteksleder giver dog udtryk for et forbehold:

"Helt grundlæggende forestiller jeg mig, at mennesker faktisk er kreative i sig selv, hvis de får lov til at få indflydelse på deres arbejde, får lov til at tænke sig om, så er det, så behøver man jo ikke gå på kursus for at være kreativ."

Man kan sige, at respondenternes opfattelse understøtter Mandag Morgens (Mandag Morgen, s. 11) 
syn på den danske innovationsmodel som en samarbejdsmodel, der i højere grad end andre modeller forbinder kreativitet med indflydelse og ansvar på arbejdet. Et af bibliotekerne forsøger at bevæge sig væk fra den individuelle uddannelse eller kursus over til, hvad organisationen - frem for individet har brug for. Her er det fællesskabet og det at få fælles oplevelser, der kommer først, når der skal tages stilling til kompetence-og vidensudvikling indenfor kreativitet og innovation. Denne tilgang matcher praksisfællesskabet godt. Et andet bibliotek har haft en medarbejder af sted på en kreativ uddannelse på Ålborg Universitet for at lære en metode til at tænke ud af boksen på. Et tredje bibliotek forestiller sig inspireret af ovenstående - at designe biblioteket som et sted, der bør være med til at åbne folks muligheder for at tænke ud af boksen, være kreative og blive inspirerede. Der er fokus på at understøtte serendipitet i flere biblioteker, fordi folk skal komme ind og inspireres, ikke nødvendigvis kun have faktuel viden, men prøve at tænke anderledes, laere at være kreative. Der skal gives rum til det. Det ligger helt på linje både med Rapporten fra Styrelsen for Bibliotek og Medier, der ønsker, at serendipitet skal understøtte kreativitet i folkebiblioteket og med Tanggaards (2008) teori om, at kreativitet skal læres. Undersøgelsen viser desværre samtidig, at der i folkebibliotekerne - med visse undtagelser - ikke er et udpræget fokus på kompetenceudvikling inden for kreativitet og innovation. De fleste kurser og efteruddannelser prioriteres i øjeblikket ud fra en nødvendighed. Afrapportering fra folk, der har været af sted på kurser, har mere tilfældighedens skær end karakter af systematisk erfaringsindsamling.

\section{Hvordan støttes kreativitet og innovation i det strategiske arbejde?}

Alle biblioteker har en innovationsstrategi, en struktureret udviklingsproces ud fra ideer, der indkaldes i organisationen på baggrund af strategiske mål, politikere, kommunen, budgetmål og mål fra Styrelsen for Bibliotek og Medier. Det er indarbejdet i kulturen. I det strategiske arbejde får medarbejderne både rammer for kreativitet, men også frihed til at udfolde sig inden for rammerne, og det bemærkes, at især nye rammer fremmer kreativitet, fordi medarbejderne her får lov til at lege deres kreativitet igennem. Det at befordre kreativiteten handler nemlig meget om, at der eksisterer nogle relationelle processer, et praksisfællesskab. Der udstikkes rammer for kreativiteten i form af strategiske mål, politik og brugerbehov, biblioteksplaner med indsatspunkter og visioner; inden for de rammer, er det så medarbejderne, der udfolder beslutningerne. Rammerne opfattes som rimeligt flydende, så gode ideer ikke kvæles, der er fx ikke et facit fra start. Kreativitet og ideudvikling forsøges på enkelte biblioteker italesat gennem konsulenter, der fx binder kultur og erhvervsliv sammen gennem samarbejde med kreative vækstcentre, hvor folk styrer og coacher processer med at få medarbejdere til at udfolde deres kreativitet. På et af bibliotekerne er der et ønske om et decideret "legerum" eller laboratorium for sociale medier. Kreativitet understøttes på mellemlederniveau i koordinationsgrupperegi, gennem projektorganiseret arbejde og pr-grupper. På lederniveau støttes kreativiteten gennem netværk, internt og eksternt, nationalt og internationalt og gennem faglig udvikling i form af videregående uddannelser som eksempelvis masteruddannelser. Interviewundersøgelsen viser, at det også sikres, at forskellige faggrupper - i overensstemmelse med Tanggaards (2008) anbefalinger - er repræsenterede i de kreative grupper. Proceskonsulenter og konsulenter, der præsenterer værktøjer som fx associationsøvelser, inddrages. Der tilbydes også workshops, kreativitets- og ideseminarer, hjælp til at formulere en ide og hjælp til at coache processer, der kan få folk til at udvikle deres kreativitet på flere biblioteker. Derudover støttes kreativitet gennem tilskud fra diverse udviklingspuljer. Flere pointerer, at det er i orden, at et projekt lander et andet sted end det planlagte; det gør ikke noget, idet man ikke må være bange for at tage initiativer. Det opfattes altså som vigtigt at være risikovillig - i modsat fald dør biblioteket. Mere generelt nævnes ros og opbakning til medarbejderne som baggrund for kreativitet og innovation.

\section{Hvordan understøtter biblioteket innovationer?}

Innovation understøttes eksempelvis gennem projektstyringsværktøjer, sparring, udviklingspuljer, eksperter, partnere, samarbejder med universiteter, vækstcentre og erhverv. Et par biblioteker har taget penge fra materialekontoen til udvikling. Man har flyttet fokus fra en udtømmende materialesamling til en flydende materialesamling og overført ressourcerne til biblioteksudvikling med stor succes. Man har forsøgt sig med en kompetencedatabase, videndeling på Facebook med profiler, men det bemærkes dog, at face-to-face kontakt i praksis stadig opleves som det bedste, hurtigste og det, der virker. Her kan man 
tale om et praksisfællesskab igen, der dog måske kan overtages af nettet, når teknologierne bliver gode nok. Der indgår kompetenceudviklingskurser ud fra, hvad der mangler i afdelingerne, (generelle kurser), deltagelse i internationalt arbejde, som Delpht fonden, Global Libraries, Eifel, der støtter biblioteksudvikling rundt omkring. Flere biblioteker nævner studieture til Amsterdam, Barcelona, Californien, Helsinki, Sverige og USA. Interviewene tyder dog ikke på et mere systematisk og bastant fokus i folkebibliotekerne på kreativ eller innovativ kompetenceudvikling.

\section{I hvilke fora opstår kreativitet og innovation i fol- kebiblioteker?}

Ifølge respondenterne fremmes kreativitet gennem mange forskellige fora. Overordnet vil projektpenge fra Styrelsen for Bibliotek og Medier typisk gå til konsortier, idet Styrelsen forlanger, at man samarbejder med andre, offentlige eller private institutioner. Det skaber naturligt nok en række større fora for kreativitet og innovation. I det enkelte bibliotek er der gennemgående faste strukturer for kreativitet. Her kan fx nævnes ledermøder, personalemøder, bibliotekarmøder, og selvstyrende teams. Der arbejdes også med kreativitet i mere uformelle fora såsom ad hoc netværksgrupper, arrangementsgrupper og pr-grupper og lign. Projekterne bestemmer hvilke fora, der er aktuelle. Det centrale er her igen praksisfællesskabet, der danner baggrund for arbejdet i de forskellige fora. Struktureret kreativt arbejde foregår typisk i projekter, og der sammensættes hele tiden nye projektsammenhænge. Der arbejdes også ofte i tværfaglige fora, der bryder op på afdelingsstrukturen i teams over tid, hvor man sparrer med hinanden. Dette er i god tråd med Tanggaard, der mener, at den bedste grobund for kreativitet, er at inddrage mange forskellige faggrupper. Eksterne fora kan være sommerskoler, universitetskurser, forlag og eksterne samarbejdspartnere.

\section{Hvilke arbejdsprocesser indgår i bibliotekets in- novative projekter?}

I de innovative projekter arbejdes der bevidst med ideudvikling i udviklingsgrupper, og der arbejdes projektorienteret og i teams over tid med milepæle og mål. De fleste folkebiblioteker arbejder meget med strukturerede udviklingsprocesser med årshjul eller lignende strukturer, hvor der indkaldes ideer fra hele organisationen, der herefter behandles på ledermøder og matches med strategiske mål, politikere og budget mål. Der arbejdes med projektstyringsværktøjer fx med modeller som Prince 2 og Fish, der er metoder til udvikling. Der udføres også forskellige forsøg med brugerinddragelse, fokusgrupper og med nye teknologier, fx teknologier, der forsøger at trække ideer ud af brugerens hoved - et eksempel er et interaktivt bord til opsamling af lyde og stemmer. Andre arbejdsprocesser er videndeling på intranet. I de innovative arbejdsprocesser indgår i nogle biblioteker på et tidligt stadie kreative fora, konsulenter og studiebesøg. Betydningen af at arbejde i netværk både inden for organisationen og ud af huset understreges, som en væsentlig proces til at omsætte kreativiteten til innovation:

"Jeg har erfaring med, at de, der har stået i spidsen for et projekt hver gang har haft fat i noget, folk der er rigtig dygtige netværkere, som kan netværke med andre mennesker, som kan skabe netværk ud af bibliotekerne med andre organisationer og hvad der nu er, folk som ikke alene får ideer, men også kan omsætte det.")

"Hvis det [kreativitet] skal blive til innovation, hvor det faktisk har en betydning for virksomheden og at det batter noget, så kræver det virkelig meget, så vil man danne netværk..."

Undersøgelsen peger ikke på mange egentlige anbefalinger til procedurer for ideudvikling, men der anvendes flere steder former for værktøjer eller en værktøjskasse, der viser, hvordan man kan gribe en proces an med generelle værktøjer for, hvordan man laver en workshop, hvordan man sikrer sig, at de forskelliges holdninger kommer frem, og hvordan får man det skrevet ned, så det kan bruges bagefter. I den forbindelse benytter flere også lærebøger. Et bibliotek har ikke nogen direkte anbefalinger til procedurer for ideudvikling, men peger på drømme og visioner:

"Hvad er det for et sted vi vil skabe, vi havde en drøm, vi havde noget vi ville, vidste vi skulle, hvordan får vi det så gjort, så vi understøtter det vi vil og hvor er det vi kan lære noget. Men systematik nej."

Kreativitet og innovation belønnes ikke direkte i folkebibliotekerne, men gennem Ny Løn er der givet 
mulighed for at belønne enkelte medarbejdere. Generelt er det dog ikke kun kreativt arbejde, men også mere rutinepræget arbejde, der belønnes, da det opfattes som støtte til at frigøre kræfter til det mere kreative arbejde. Der er fx funktionsgrupper for læring, der får funktionsløn, og kvalifikationstillæg er meget brugt omkring innovation. Der er også arbejdet med resultatløn, men ikke så meget mere.

\section{Hvor får biblioteket ideerne fra?}

Undersøgelsen viser, at ideerne hentes fra mange forskellige steder. I organisationen på lederplan fra lederkolleger, biblioteksfaglige sammenhænge, kulturelle sammenhænge, nationalt netværk for centralbibliotekarer, lokalt netværk for ledere og 4-6 årlige videndelingsmøder for hele personalet, frie møder og udviklingsmøder for blot at nævne nogle af kilderne. Der tegner sig også et klart mønster af, at brugerne opfattes som en helt central kilde til ideer. I mindre grad direkte end indirekte, idet udgangspunktet for ideerne kan være mange forskellige typer af brugerundersøgelser, fokusgrupper og andre grupper, der høres, ligesom også teknologien i høj grad inddrages med henblik på at vriste ideer ud af borgerne. Det anføres, at der er i mødet med borgerne og med andre fagligheder opstår mange ideer. Fra partnerskaber i forhold til kulturinstitutioner, fra borgerservice i samarbejdet med nye kolleger, hvor man er tvunget til at finde nye løsninger både i forhold til nye kolleger og i forhold til at løse nye opgaver. Igennem samarbejdspartnere skabes der synergieffekt og ideer opstår. Ideerne kommer også ved at give medarbejderne muligheder for at prøve nogle nye ting og ligeledes gennem indførelse af nye biblioteksbegreber såsom folkebiblioteket i videnssamfundet, gennem en innovation som det at lave flere kulturcentre, borgerservice, det tredje sted etc. Ledere og medarbejderne tvinges til noget nyt. En enkelt biblioteksleder nævner et fremtidsværksted med 10-15 kreative mennesker fra biblioteket og ledere i kommunen som kilde til ideer i forbindelse med innovation. Alle adspurgte nævner studierejser såvel nationalt som internationalt. Også i litteraturen hentes der ideer, fx fra Ray Oldenburg: "Det tredje sted" og William J. Mitchell: "E-topi: Urban Life Jim but not as we know it", Jan Gehl: "Livet mellem husene" og "Unlease the Users," ligesom danske forskere fra IVA har givet materiale til ideer. I forbindelse med etablering af biblioteker sammen med borgerbetjeningen er der brugt litteratur som Dorte Skot Hansens "Byen som scene", "Folkebiblioteket under forvandling", Biblioteksforeningens "Biblioteksrummet" og "All that and books too" af Jochumsen og Hvenegaard. Også litteratur fra masteruddannelser og andre videregående teoretiske uddannelser har ind imellem givet ideer. Der eksisterer således til en vis grad nogen indhentning af forskningslitteratur i forbindelse med innovationer, men ikke en systematisk indsamling.

Der er lidt forskellig holdning til, hvor innovationen skal komme fra:
"Brugerinnovation har fanden skabt....Jeg siger, at hvis brugerne skulle have bestemt, hvordan det her bibliotek var kommet til at se ud, så havde vi ikke fået skabt det her bibliotek. Det skyldes noget helt andet, det skyldes eksperterne har været inde over, drømmerne har været inde over og det er der, der skabes det store det nye."
"Innovation har altid udgangspunkt i brugerens hverdag...ikke det der med at spørge, hvad synes du egentlig vi skulle lave...men som med parfu- mefirmaer, de bruger fokusgrupper til at afgøre er det her godt, prøv at sætte ord på, nøjagtig det samme kan man gøre med biblioteksservice."

Alle bibliotekerne kopierer eller lader sig inspirere af andre biblioteker såvel indenlandske som udenlandske gennem studiebesøg. Det er en gammel praksis inden for biblioteksvæsenet, og alle er enige om, at det er vigtigt og udbytterigt. Der hentes rigtig mange nye ideer fra udlandet: England, Holland, Singapore, Skandinavien, Spanien, USA, m.fl.; her kan man derfor tale om et praksisfællesskab på højeste niveau, hvor der udveksles og inspireres til nye innovationer. Grundlaget for at vælge en ide til eller fra beror i første omgang på en økonomisk, samfundsmæssig og politisk nødvendighed, penge, ressourcer og gode faglige ideer. Ideen skal matche de overordnede strategiske og politiske mål og matches med budgettet. Der bliver også set på, hvem der er bagmænd eller - kvinder, tror man på det, hvordan er mavefornemmelsen, ligner det her noget, der kunne blive til noget? Der tages chancer, og det mener man er nødvendigt; masser af projekter falder på gulvet, fordi de af en eller anden årsag bare ikke kan ende med at blive til noget. Det skal give mening i forhold til samfundsmæssige nødvendigheder eller en samfundsmæssig kulturpolitisk dagsorden - ellers fravælges ideen. Der synes derfor umiddelbart at være andre 
parametre i spil end evidensbasering og dokumentation, når det skal afgøres hvilke ideer bibliotekerne vælger at føre ud i livet.

\section{Benytter folkebibliotekerne sig af forskningsre- sultater og i hvilken udstrækning ligger der forsk- ningsresultater til grund for folkebibliotekernes ide udvikling?}

Generelt er ingen af de interviewede fortrolige med begrebet evidensbasering eller evidensbaseret biblioteksfunktion. De fleste er kun fortrolige med EBP i form af erfaringsbaseret evidens - dog ikke i nogen udstrakt eller systematisk grad. Der er en del biblioteker, der har erfaringsbaseret evidens i form af guides til og rapporter om metoder til udvikling af innovationer fx brugerdreven innovation. Et enkelt bibliotek oplyser at have arbejdet evidensbaseret $\mathrm{i}$ forbindelse med innovation, men understreger, at det i så fald er ubevidst.

Grundlæggende foregår der ikke nogen systematisk evidensbasering af folkebibliotekernes praksis i forhold til innovationer. Forskningsresultater benyttes generelt i svingende grad og et par steder nærmest ikke; nogle biblioteksledere synes, at forskningen er vigtig, at der er viden at hente, og at det giver bibliotekerne mere vægt og tyngde, når man har et forskningsgrundlag; for andre er forskningen mindre vigtig end andre parametre såsom strategiske mål, politiske mål, brugerne og studierejser i ind og udland. I den udstrækning, bibliotekerne er blevet gjort opmærksomme på, at der forelå relevant forskning, som de kunne bruge, ville de gerne benytte den, men overordnet er innovation noget meget praksisnært og ikke-dokumenteret. Der er tydeligvis en bevidsthed om, at bibliotekerne givet ser forbi noget, og at der på nogle felter helt oplagt er forskning, der kunne benyttes. En af barriererne for at benytte forskningsresultater er dårlig tid. Man er således ikke uvidende om forskningens betydning. Litteraturen menes dog ikke at flytte alverden, og i den forbindelse nævnes det, at tidsskriftet Dansk Biblioteksforskning er blevet for langhåret for de fleste. Formidlingen af forskningslitteraturen er derfor vigtig, ligesom det er nødvendigt med tid og rum til fordybelse, hvis forskningsresultater skal indgå i folkebibliotekerne i forbindelse med innovation. En anden barriere for evidensbasering er henvisninger til, at bibliotekerne har en meget praktisk tradition, hvor det anses for vigtigt, at kulturpolitiske værdier er til diskussion og ikke kun er evidensbaserede, men også politiske. Det er ikke evidensbaseret forskning, der skal bestemme, hvordan bibliotekslovens værdier skal udspille sig, men derimod relationerne til borgerne, til personalet og til andre biblioteker. Frem for at være evidensbaseret, er den måde bibliotekerne arbejder på relations- og erfaringsbaseret - også selvom uddannelsen på IVA er blevet akademiseret. Undersøgelsen viser et fælles mønster, der peger på, at brugbarheden af forskningslitteraturen i folkebibliotekerne afhænger af dens værdi i forhold til praksis - det må ikke kun være teorier. Systematiske reviews kan derfor bruges som en del af ideudviklingen, hvis ideerne kan omsættes i praksis. En enkelt informant giver udtryk for, at hvis man ikke er god til at drømme eller har så mange inspirationskilder, kan det være vældig fornuftigt at få det andre steder fra. Om det så er fra forskningslitteratur, kunstnere, eller folk der har forstand på at være helt anderledes og ikke har forstand på biblioteker er ligegyldigt; informanten tilføjer, at han aldrig selv ville finde på at læse forskning:

Altså jeg arbejder ikke på den måde. Og jeg kunne ikke drømme om at gøre det. Jeg tror jeg, bare tanken om at jeg skulle opsøge det, ville allerede få mig til at kede mig... Jeg ville kede mig. ... Jeg er ikke forsker, jeg er ikke analytiker, jeg er ikke systematiker...jeg siger, hvad siger min mave mig?"

\section{Folkebibliotekernes holdning til evidensbasering af innovationer herunder hvilke fordele og hvilke ulemper er der ved evidensbasering?}

Fordelen mener man er, at det er mere kvalificeret at benytte vidensressourcer, og at det er et uudnyttet potentiale. Der er også en klar bevidsthed om, at der er sket en akademisering med professionalisering af organisationen på alle måder: kompetencemæssigt, organisatorisk og i forhold til output til brugerne, som led i en udviklingsstige, der kan medføre brug af forskningslitteratur og EBP. Fordelen er, at så er man sikker på, at det virker. Fordelen er også, at det giver dokumentation og tyngde bag beslutninger, og at man får fjernet det støvede biblioteksbegreb. Evidensbasering af sorteringsanlæg og bibliotekernes nytteværdi i samfundet, nævnes som eksempler på områder, hvor evidensbasering ville være værdifuld.

Ulempen er påpeges det samtidig, at der er for lidt relevant dansk biblioteksforskning, at det kan være svært at finde relevant litteratur inden for et emne, 
og endelig at tiden ikke er til det. EBP opfattes af nogle som noget "retro", i en situation, hvor bibliotekerne står i en "cutting edge" i front. Det er et udbredt synspunkt, at forskningslitteraturen bevæger sig for langsomt, og at der egentlig ikke findes noget litteratur, der er fornuftig, fordi den er forældet, når den udkommer, fordi der hele tiden sker så mange nye ting. Evidensbasering kan være en metode for store projekter, men man savner en hurtig løsning på organisationsplan a la Starbucks kaffebar, hvor man afprøver beta-løsninger hver uge, en trial and error model. Forskningslitteraturen opfattes også som værende for meget på det ideologiske plan og med for få konkrete services omend mentale modeller af biblioteker har været benyttet. Der er brug for hands on og praksisorienteret stof og der er en opfattelse af, at der teoretiseres for meget. Endelig er der en enkelt, der stiller spørgsmål ved begrebernes indbyrdes afhængighed:

"Jeg mener, der består en modsætning mellem de tre begreber kreativitet, innovation og evidensbasering. Når tingene er afprøvede i forvejen, er der ikke behov for kreativiteten og innovationen."

Her kan man dog anføre, at det er et spørgsmål om, hvad der kommer først ægget eller hønen og om behovet for videreudvikling af innovationer og lokale tilpasninger.

\section{Hæmmer evidensbasering kreativitet? Er der en modsatning mellem kreativitet og evidensbase- ring?}

De fleste mener ikke, at evidensbasering vil hæmme kreativiteten. En enkelt mener dog, at evidensbasering kan hæmme kreativitet, men ikke innovation; andre igen mener det vil hæmme dem personligt, fordi de arbejder på en måde, der ikke lader sig forbinde med den systematik, som er knyttet til evidensbasering. Der eksisterer også en uvilje mod teoretisering og tunge rapporter, og at det ikke bliver mødet mellem medarbejderne og borgeren, der vil komme til at danne baggrund for innovationer, men at evidensen bliver afgørende. Der er dog enighed om, at man selvfølgelig skal bruge forskningsresultater, men kun som et parameter blandt flere.

\section{Hvem skal i givet fald foretage evidensbaserin- gen?}

Bibliotekerne forestiller sig flere scenarier omkring EBP. Alle forestiller sig en eller anden form for et center, der indsamler og formidler evidens i form af systematiske reviews. Det skal ikke ligge spredt over 15-16 steder. Det kunne være Det informationsvidenskabelige Akademi, (IVA) der samlede og udgav reviews eller Styrelsen for Bibliotek og Medier. Styrelsen sender to gange årligt nationale opgaver af overbygningskarakter ud, og her kunne evidensbasering med systematiske reviews eventuelt indtænkes, fordi meget af biblioteksudviklingen har været drevet i kraft af Styrelsen for Bibliotek og Medier. Styrelsen kunne måske give et opstarttilskud til et sådant center. Flere nævner, at Styrelsen for Bibliotek og Medier engang lavede en projektdatabase, hvor bibliotekerne skulle melde ind, hvordan man genbruger ideer, og derigennem stimulere videreudvikling og genbrug af ideer. Centralbibliotek.dk foreslås også som en mulighed, hvor man kunne lægge en samling af systematiske reviews ind. Overvejende er det dog IVA, man mener, skal stille systematiske reviews til rådighed. IVA har forudsætningen for både at kunne indsamle evidens gennem forskning og formidle den. Det er opfattelsen, at hvis bibliotekerne får en meget stærkere position over for borgerne, giver det mening, at IVA laver arbejdet. Et enkelt bibliotek foreslår, at medarbejderne supplerende kunne skabe en samling af reviews ud fra en søgning på det aktuelle emne. Andre mener derimod ikke, at det er en opgave for det enkelte biblioteks medarbejdere. Bibliotekerne har behov for noget i kort udgave, som de kan bruge strategisk.

Dansk Biblioteksforskning foreslås som formidlende kilde af anvendelig forskning, fordi den ses af alle, og fordi det ofte er medarbejderne, der gør opmærksom på litteraturen. Det fremhæves, at der skal fokuseres på en forståelig formidling af forskningen og den skal kanaliseres ud, så den er let at få fat på. Og så skal det være noget, der relaterer til bibliotekerne - her nævnes Dorte Skot-Hansens forskning som noget, der er blevet brugt på stort set alle biblioteker. Flere andre forskere fra IVA nævnes også. Det foreslås også at igangsætte nogle Ph.D.er på konkrete projekter med afkast i evidens. Enkelte betoner et samspil mellem IVAs forskningsresultater og bibliotekernes erfaringsbaserede praksis i et center. 


\section{Har I inden for de sidste fem år lavet en informa- tionssøgning med henblik på innovation?}

Alle biblioteker har inden for de sidste fem år lavet informationssøgninger med henblik på aktuelle emner, men ikke alle med henblik på innovation. Nogle biblioteker har i forbindelse med Innovation Cup lavet søgning på innovation og biblioteker. Der søges i øvrigt som en selvfølge litteratur, når man er i gang med forskellige processer; oftest er innovationer dog mere baseret på studiebesøg og den litteratur, der ligger lige for end på forskningslitteratur. Derudover mener man, at hvis man skal være rigtig innovative, skal der ikke kun inddrage biblioteksforskning men også anden forskning. Ingen af bibliotekerne har abonnement på Library Information and Science Abstracts (LISA), (en abstractservice inden for biblioteksforskning, informationsvidenskab, informationssøgning m.m.); flere kendte ikke til databasens eksistens. Der har været fremsøgt forskningsbaseret litteratur i forbindelse med deltagelse i videregående uddannelser.

\section{Diskussion}

Med afsæt i Tanggaards (2008) kreativitetsbegreb (at kreativitet skal læres, at kreativitet og innovation hænger sammen, og at kreativitet forudsætter viden og færdigheder inden for eksisterende praksis og den nyeste udvikling), kan man argumentere for en evidensbasering af innovationer i folkebiblioteker. Evidensbasering skaber erfaringsopsamling, som kan danne baggrund for videndeling internt i organisationen og eksternt mellem organisationer og institutioner.

Tanggaard (2008) peger endvidere på, at ens verden skal være stor nok for, at man kan blive ved med at være kreativ. Det er ikke nok bare at være kreativ med de ting, man allerede kender, man skal kende til omkringliggende viden og den nyeste udvikling på sit felt for at kunne drage det ind i sin egen praksis. Denne pointe peger ligeledes på evidensbasering $\mathrm{i}$ Rieper og Foss Hansens forstand og på inddragelse af forskningslitteratur med systematiske reviews i bibliotekernes praksis. Vi kan med afsæt i undersøgelsen sondre mellem på den ene side den praksisbaserede evidens og på den anden side den forskningsbaserede evidens.
Evidensbasering kan udfoldes på flere niveauer: 1) hos den enkelte praktiker, 2) på organisatorisk ledelsesniveau og 3) på et overordnet institutionelt niveau. Da den danske innovationsmodel repræsenterer en samarbejdsmodel, der i højere grad end andre forløser kreativitet hos sine medarbejdere, der har mere ansvar og selvstændighed end andre landes medarbejdere (Mandag Morgen, 2005) kombineret med, at kreativitet kan læres og at innovationer vokser nedefra omkring praksisfællesskaber (Tanggaard, 2008), kunne man argumentere for en praksisbaseret, blød evidens, hvor det er 1) den evidensinformerede praktiker og 2) ledelse eller afdeling, der selv samler evidensen og benytter den i praksis som baggrund for kreativitet og innovation. Da der imidlertid ikke er tradition for systematisk forskning og udvikling $i$ tilknytning til innovation i folkebibliotekssektoren, kan det blive vanskeligt tidsmæssigt, i forhold til den daglige praksis og mentalt i forhold til en kulturændring at indbygge en systematisk og velkontrolleret evidensbasering gennem folkebibliotekernes egne medarbejdere; det vil kræve tid og rum og en politisk funderet baggrund. Det vil også kræve en mentalitetsændring. Med akademiseringen af uddannelsen på IVA kan det meget vel være et generationsspørgsmål, hvornår medarbejderne opfatter systematisk evidensbasering og anvendelsen af forskningslitteratur som en selvfølge. Det tredje niveau evidensbasering kan udfoldes på, er det institutionelle, hvor evidensbasering med systematiske reviews kan styres og formidles fra en overordnet institution eller et center. Undersøgelsen viser, at bibliotekslederne og udviklingscheferne foretrækker evidensbasering via en overordnet institution eller et center, der indsamler og formidler systematiske reviews, og at formidlingen her er meget vigtig. Afslutningsvis skal det bemærkes, at den optimale kvalitetssikring af innovationer på baggrund af den teoretiske gennemgang og undersøgelsen ses som en kombination af de tre nævnte niveauer i samspil og som en mulig kombination af blød og hård evidensbasering. Konsekvenserne af manglende evidensbasering kan blive oversete og spildte muligheder for udvikling, som det allerede antydes i nogle interviews. Det kan på sigt blive dyrt i ressourcer og penge.

\section{Konklusion}

Folkebibliotekernes holdning til kreativitet er til en vis grad præget af en traditionel opfattelse af kreativitet, som en individuel kompetence; nyere forskning 
peger dog på et mønster, hvor kreativitet og innovation først og fremmest opstår i et praksisfællesskab i mange forskellige fora internt som eksternt. Innovation er mere end blot kreativitet; det er noget nyt og noget brugbart, selve iværksættelsen af den kreative ide. Det fremhæves, at en bevidst blanding af forskellige fagligheder i stedet for en traditionel monokultur ligesom en vis frihed til at udfolde kreativitet, er med til at skabe grobund for kreativitet og innovation. Kreativitet kan til en vis grad læres, men undersøgelsen viser, at der med visse undtagelser ikke er udpræget fokus på kompetenceudvikling inden for kreativitet og innovation i de undersøgte folkebiblioteker. Dette skyldes at kreativitet kræver rum, fordybelse og tid, og at kompetenceudviklingen bærer præg af økonomisk nødvendighed, selvom der i høj grad er fokus på innovation i det strategiske arbejde.

Der findes ingen egentlige anbefalinger til procedurer for ideudvikling, men medarbejderne får typisk udstukket rammer for kreativitet med en vis frihed til ideudvikling. Alle biblioteker har en innovationsstrategi med en struktureret udviklingsproces ud fra idéer, der indkaldes i organisationen ud fra strategiske mål, politik, budget og brugere, og der eksisterer en række procesværktøjer, der tages i brug med henblik på innovationer. Der er ingen belønningssystemer for kreativitet og innovation, men Ny Løn giver en række muligheder, dog er det i givet fald ikke kun kreativitet, der belønnes, men også drift. Undersøgelsen viser, at bibliotekerne får idéerne fra den enkelte organisations medarbejdere, brugerne, biblioteksfaglige og kulturelle sammenhænge, eksterne partnere, studierejser i ind- og udland og at bibliotekerne kopierer andre bibliotekers idéer evt. med lokal tilpasning. Grundlaget for at vælge idéerne til eller fra er økonomi, samfundsmæssig og politisk nødvendighed og brugerne. Idéerne skal matche overordnede strategiske mål, og det har betydning, hvem der står bag idéerne. Der blev fundet enkelte spor af erfaringsbaseret evidens i folkebibliotekerne i form af rapporter og guides til biblioteksinnovationer, men ellers er innovation praksisnær og ikke-dokumenteret.

Folkebibliotekerne benytter sig generelt ikke af forskningsresultater, og der ligger derfor heller ikke i nævneværdig grad forskningslitteratur til grund for folkebibliotekernes ideudvikling. Undersøgelsen viser dog - med en enkelt undtagelse - at bibliotekerne ikke mener, at evidensbasering vil hæmme kreati- vitet, og at evidensbasering derfor kan indgå som et parameter blandt flere.

Der tages dog forbehold over for evidensbasering som den dominerende eller eneste parameter for biblioteksinnovationer. Formidlingen af forskningen er vigtig for alle biblioteker. Systematiske reviews bør indsamles og formidles fra et center - de fleste peger her på IVA, enkelte på Styrelsen for Bibliotek og Medier. Den optimale kvalitetssikring af innovationer ses som en kombination af blød og hård evidensbasering. Afslutningsvis giver hverken Tanggaards teori eller opfattelsen hos flertallet af interviewede biblioteksledere tilsyneladende belæg for at hævde, at der skulle være en - reel eller oplevet - modsætning mellem evidens-baseret praksis (EBP) og kreativitet og innovation

\section{Referencer}

Booth, A \& Brice, A (Eds.) (2004). Evidence-based practice for information professionals. London: Facet Publishing.

Pratt, AC \& Jeffcut, P (2009).Creativity, Innovation and the Cultural Economy, London: Routledge.

Darsø, L (2001). Innovation in the making. Frederiksberg: Samfundslitteratur.

Folkebibliotekerne $i$ vidensamfundet. Lokaliseret 2.10.2010 på http://www.bibliotekogmedier.dk/fileadmin/publikationer/rapporter_oevrige/folkebib_i vidensamfundet/pdf/Folkebib_i_videnssamf.pdf

Information (2010). Biblioteker er blevet virksomheder, hvor kunderne bestemmer. Lokaliseret 26.01.2010 på http://www.information.dk/219166

Kollerup, F \& Thorball, J (2005). Innovation for ildsjcele \& vandbcerere. København: Børsen.

Mandag Morgen (2006). Det innovative bibliotek: en strategisk partner $i$ svaret på globaliseringens udfordringer. København: Huset Mandag Morgen A/S, Biblioteksstyrelsen.

Mandag Morgen (17.01.2005) Om evidensbasering $i$ det offentlige. Lokaliseret 28.01.2010 på http://www. $\mathrm{mm}$.dk/virker-velfærden-et-debatoplæg-om-evidensog-velfærd. 
Mikkelsen, T (2009). Kreativitetens psykologi. København: Nyt Nordisk Forlag Arnold Busck.

Rieper, O \& Foss Hansen, H (2007). Metodedebatten om evidens. København: AKF Forlaget.

Folkebiblioteket som forvandlingsrum; perspektiver på folkebiblioteket $i$ kultur- og medielandskabet (2006). L. Emerek, C. Hvenegaard Rasmussen \& D. Skot-Hansen (Red.). Kbh.: Danmarks Biblioteksforening, Danmarks Biblioteksskole.
Qvortrup, L (2007). Folkebiblioteket under forvandling. Information, den 11. 04. http://www.iva.dk/omiva/nyheder/insight/artikel/default.asp?cid $=2816$

Styrelsen for Bibliotek og Medier (2006). Rapport Strategi: fra information til viden: på vej til vidensamfundets bibliotek. 14 sider. Lokaliseret 4.10. 2010 på http://www.bibliotekogmedier.dk/

Tanggaard, L (2008). Kreativitet skal laeres! Når talent bliver til innovation. Aalborg: Aalborg Universitetsforlag. 